\title{
The Portuguese Special Operations Forces as Instrument of Foreign Policy: The Case Study of Afghanistan
}

\author{
João Reis and Sofia Menezes
}

\begin{abstract}
The aim of this paper is to provide an exploratory overview of the Portuguese special operations forces as instrument of foreign policy. In doing so, we disclose new dynamics that Portugal employing in fragile states and we discuss its implications for the North Atlantic Treaty Organization. The research methodological approach falls into a qualitative case study research, which includes more than one method of data collection for triangulation and corroboration purposes. We have found that Portugal is trying to intensify its international relations within the EU, UN and the NATO, while the Portuguese special operations forces have been playing an important role to strengthen its presence within these international institutions. The new dynamics that Portugal is seeking are based on the democratic values, the rule of law and the human rights, to dissociate itself from the colonial legacy and thereby find new avenues of influence. Further research should focus on the new strategic priorities for the Afghan Government and NATO, as these priorities are changed at a relatively fast pace.
\end{abstract}

Keywords Portugal $\cdot$ Afghanistan $\cdot$ Special operations forces $\cdot$ Foreign policy $\cdot$ Case study research $\cdot$ European Union $\cdot$ United Nations $\cdot$ North Atlantic Treaty Organization

\section{Introduction}

This paper focuses the Portuguese special operations forces as instrument of foreign policy in Afghanistan. We have selected Afghanistan because this country has played a major role with great regional empires of Persia, India and China in late medieval

\author{
J. Reis (凶) \\ Department of Military Science, Military Academy, GOVCOPP, Lisbon, Portugal \\ e-mail: joao.reis@academiamilitar.pt \\ S. Menezes \\ Department of Management and Leadership, CINAMIL, Lisbon, Portugal \\ e-mail: sofia.menezes@academiamilitar.pt


and early contemporaneous period [1]. The country is known as the graveyard of empires [2] that reputation invokes the British and Soviet defeats in several wars in the nineteenth and twentieth century, to argue that Afghanistan is an unconquerable quagmire that inevitably dooms even the strongest army that venture there [3]. Moreover, Afghanistan was the first major test for state-building in the twenty-first century and embroiled the USA and its allies for almost two decades [4].

Afghanistan required virtually every North Atlantic Treaty Organization (NATO) member's participation, including Portugal, and its participation is far from certain. Most probably, the economic and political assistance will continue, even after the Afghan forces assumed full security responsibility at the end of 2014-the new, smaller, non-combat mission Resolute Support (January 1st, 2015-until recent days) began to train, advise and assist (TAA) the Afghan security forces and institutions [5].

We have chosen the well-trained special operations forces instrument due to its strategic value, as they were the first to be deployed to Afghanistan, and they will be probably the last to redeploy. The objective of this research is to ascertain the suitability of the Portuguese special operations forces within the NATO Resolute Support Mission (RSM) and its relevance as an instrument of foreign policy for Portugal.

We have structured this paper in four sections after the introduction, as follows: we begin by a review of the literature; secondly, we describe the methodological approach; then, we investigate the relevance of the special operations forces to NATO and Afghanistan; in the last place, we provide the implications and suggestions for subsequent research.

\section{Theoretical Background}

\subsection{Allied and the Portuguese Army Special Operations Forces}

NATO Allied Joint Publication (AJP) defines that special operations as military activities conducted by specially designated, organized, trained and equipped forces, manned with selected personnel, using unconventional tactics, techniques and modes of employment-special operations deliver strategic or operational-level results or are executed where significant political risk exists [6]. On the other hand, the NATO special operations headquarters define special operations as operations that may be conducted across the spectrum of conflict as part of article 5 (collective defence) or non-article 5 (crisis response operations) to fulfil NATO's three essential core tasks-collective defence, crisis management and cooperative security [7]. The NATO special operations headquarter also describes the special operations missions to include suitable combination or all of the principal tasks of military assistance (MA), special reconnaissance (SR) or direct actions (DA), depending on the circumstances of each operation. While special operations mission may range from 
small unilateral actions to large-scale activities of a combined and joint nature, they are tailored to contribute to the accomplishment of the defined political and military/strategic objectives.

Each type of special operations missions may be defined as follows: DA is the use of a rapid offensive operations to destroy or capture a target, usually by means of secrecy and surprise [8,9]; SR involves covert collection of intelligence typically in denied enemy areas [9, 10]; MA involves the provision of training and advising to host nations to improve their skills and capabilities $[8,9]$.

In Portugal, an order from the Chief of Staff of the army (directive ${ }^{\circ}$ 90), October 28th, 2007, determines that special operations are divided in special reconnaissance, direct actions and military assistance. The forces that develop special operations may be employed across the spectrum of operations. In view of its unique characteristics, it constitutes adequate forces to perform tasks within the crisis response operations (CRO), combat operations for search and rescue (CSAR) and counterterrorism operations, consisting in forces especially suitable in counterterrorism [11]. The same directive from the Chief of Staff of the Portuguese army states that: (1) SR objective is to obtain strategic and operationally sensitive information, it can use sophisticated methods, techniques (e.g. human intelligence) and equipment [11]; (2) DA is a precise action, which is usually performed on well-defined targets, high criticism and high value, with strategic or operational significance. The use against tactical objectives is justified only by the action of criticality or by the inadequacy or unavailability of the use of other forces [11]; (3) MA consists of a broad framework of measures in support of friendly or allied forces and populations in peace, crisis or conflict, in situations of need for security and survival, but also development. The MA also fits into all activities related to the actions of military-technical cooperation, support in situations of disaster and conflict mediation [11].

The missions developed by the Portuguese special operations forces are similar to reference countries and NATO members. This section has the objective to define the elementary concepts, which are going to be necessary for the following sections.

\subsection{Resolute Support Mission and the Afghan Government}

The RSM in Afghanistan is focused on train, advise and assist (TAA) the Afghan security forces. Historically, the USA special operations forces (SOF) have had the responsibility to TAA foreign military forces. Even if today, the US National Security Strategies introduced the US military services (Army, Navy, Air Force and Marines) to organize, train and equip themselves to carry out these activities at a larger scale with conventional (non-SOF) forces [12]. Livingston [12] remarks this responsibility in a broader sense of building the capacity of partner states that has been termed security force assistance (SFA). SFA is part of the USA and NATO strategic goal of having Afghanistan responsible for their security. Usually, SFA is directly linked to counterterrorism strategy and is the key to engage underdeveloped and undergoverned nations, often referred to as weak or fragile states. 
In Afghanistan, the SFA mission is in part attributed to the NATO special operations component command-Afghanistan. This command brought together NATO and other coalition special operations forces into the same operational headquarters, and it demonstrates both that NATO special operations forces have made major progress in integration and can potentially be a major part of the alliance capability [9]. The created synergies among special operation forces community achieve significant effect due to the combination of different techniques, technologies and expertise. Long [9] reinforces the idea of NATO special operations forces that actively performs three main allied special operations forces missions, i.e. military assistance, special recognizance and direct actions; but particularly, the military assistance mission to develop the Afghan police special units was its core mission.

Strandquist [13] also performed a research which suggests the USA and their allies should change their strategy in Afghanistan, since developing military combat operations against the insurgents is not enough and the future will have to go through a focus on the development of local communities to counter-insurgency and that the Afghan central government should win their support.

During the war in Africa (1961-1974), the Portuguese armed forces also used the same techniques, in order to obtain public support, as it may be one of the key points to win the war in Afghanistan. This technique was also used in Vietnam and it had been termed "winning hearts and minds" [14]. The term was firstly used by Louis Lyautey, a French army marshal and minister of war. The term included not only military, but also social actions and improvements in the quality of life [15]. Later, Grochowski [16] published an article concerning the Takur Ghar battle, a short, but intensive, military operation that engaged the US special forces and Al Qaeda insurgents in Afghanistan. According to Grochowski [16], the Takur Ghar battle demonstrated the short lead-time and short-duration high-intensity tempo of the special operations missions regarding the war against non-state actors and particularly violent extremist organizations. The course of Afghan conflict and the commitment of the coalition of special operations forces has focused on the tactical objectives, but with time, this path has changed, i.e. the current conflict requires special operations forces highly committed to TAA the Ministries of the Government of the Islamic Republic of Afghanistan (GIRoA), which creates strategic and political objectives for a rapid development of the Afghan Security Forces and its population.

\subsection{Brief Overview of the Portuguese Foreign Policy}

Between April 1974 and January 1986, the Portuguese foreign policy oscillated between two basic orientations, which marked two distinct phases: the transition to democracy and the democratic consolidation [17]. Teixeira [17] also portrays the Portuguese position in the Euro-Atlantic binomial, in the post-colonial relations regarding the new multilateral triangle and based on foreign policy values, which we summarize as follows: (1) The Europe-Atlantic binomial remains the geopolitical equation: Portugal as an EU country seeking to promote and enhance not only the 
Atlantic position between Europe and the USA, but also the post-colonial relations (African Portuguese-speaking countries), the key for the strategic guidelines of the foreign policy of democracy [17-19]; (2) Portugal seeks participation in terms of producing international security, such as the military presence in organizations as NATO, EU and UN (the new multilateral triangle), which has provided not only a factor of military modernization, but also the external credibility of the Portuguese State. The armed forces have become a foreign policy tool [17, 19, 20]; (3) The challenge is in the global plan of international security, in an environment marked by terrorism, ethnic and religious conflicts; that is why the framework of security has to be cooperative security $[17,21]$; (4) The presence of the Portuguese armed forces in peacekeeping missions under the umbrella of the UN confirms the diplomacy of values that had the independence of Timor as one of its major hits [17]; (5) Lastly, foreign policy always comes from the formulation of interests. However, the contemporaneous democratic model ignores the interests of the states and focuses on the human values. The values for Portugal are democracy, the rule of law and human security [17].

Similarly, Santos [22] argues about the use of the armed forces which is one of the most important instruments available to support its foreign policy, giving it a specific weight within the security scope.

\section{Methodology}

The methodological approach falls into a qualitative case study research. This research therefore uses a contextual rich data setting from the real world to investigate a phenomenon which is understudied. We do use multiple sources of data collection [23], i.e. semi-structured interviews, official documents and direct observations, for data triangulation and corroboration purposes [24]. The data collection method focused on ten interviews from two military branches of the NATO Result Support Mission in Afghanistan; the non-classified documents were collected from open sources; and the direct observations have collected from informal interviews and personal field notes of the observed reality. The field study took place in Kabul, Afghanistan during the following periods: February to July of 2015 and from August 2017 to February 2018. Furthermore, for confidential reasons, all the respondents kept their anonymity and the collected reports came from unclassified sources. The goal of the case study is to gain a holistic view of the phenomenon and to understand the specific reality that is being discussed in this paper [25].

\subsection{Data Collection Techniques}

The interviews were the primary data collection method for this case study. Quivy and Campenhoudt [26] reported the interviews as a method that differs from others 
in the extent that it refers to the fundamental processes of communication and human interaction. The same authors also mentioned that this technique, when properly valued, enables the researcher to withdraw information and very rich reflection elements from interviews. However, we know that, sometimes, respondents can provide the interviewer with that he wants to hear, resulting in poor and inaccurate responses [24], which may be mitigated through the use of other data collection techniques.

The sample selection comprehended ten interviews, divided into two groups of five. Both groups served under the command of the NATO special operations component command-Afghanistan. The first five are servicemen from the US special operations and the second group are servicemen from the Portuguese (PRT) special operations forces. The US and PRT officers have interacted with the most senior levels of the Afghan Ministry of Interior and directly influenced the long-term strategy to sustain the Afghan Special Security Forces (ASSF). To get different perspectives, we have also collected a contribution from some Portuguese commissioned officers that have worked as staff officers from the Special Operations Advisory Analysts.

The case study protocol was based on the Portuguese National Defence Strategy (PNDS), which was approved by the resolution of the Portuguese council of ministers 9/2013, April 5th, 2013. The PNDS was developed according to three main vectors: (1) national sovereignty - neutralization of threats and risks to national security, (2) actions to national vulnerabilities and (3) enhancement of the resources and national opportunities. Each vector is divided of several strategies ( 20 strategies in total), and each strategy is subdivided into lines of action (116 lines of action in total)-for that reason, it was impossible to display all the National Defence Strategy strategies in short paper.

The national vectors, the strategy and the several lines of action contributed directly or indirectly to the achievement of permanent and short-term national goals in Afghanistan. The contribution of both groups was based on the choices of each (1) vector, the corresponding (2) strategy and the (3) lines of action from the PNDS (vide Table 1).

Table 1 Vectors, strategies and lines of action of the Portuguese national defence strategy

\begin{tabular}{l|l|l}
\hline Vectors & Strategies & Lines of action \\
\hline $\begin{array}{l}\text { Exercise sovereignty, } \\
\text { neutralize threats and } \\
\text { risks to national } \\
\text { security }\end{array}$ & $\begin{array}{l}\text { Consolidating } \\
\text { external defence } \\
\text { relations }\end{array}$ & $\begin{array}{l}\text { Intensifying external relations and } \\
\text { defence cooperation with the US }\end{array}$ \\
\cline { 2 - 3 } & $\begin{array}{l}\text { Defending Portugal's } \\
\text { international position }\end{array}$ & $\begin{array}{l}\text { Reaffirm the strategic importance of the } \\
\text { inclusion of Portugal in NATO, as well } \\
\text { as the bilateral alliance with the US }\end{array}$ \\
\cline { 2 - 3 } & $\begin{array}{l}\text { Consolidating } \\
\text { external defence } \\
\text { relations }\end{array}$ & $\begin{array}{l}\text { Participate in international military peace } \\
\text { missions, particularly in the context of } \\
\text { the UN, NATO and EU }\end{array}$ \\
\cline { 2 - 3 } & $\begin{array}{l}\text { Defending Portugal's } \\
\text { international position }\end{array}$ & $\begin{array}{l}\text { Strengthen the presence of the } \\
\text { Portuguese in international institutions }\end{array}$ \\
\hline
\end{tabular}


To ensure the data corroboration, we have used other data collection techniques, i.e. secondary sources, such as direct observations and official documents. We did not give priority to these data collection techniques, but they were essential for triangulation and corroboration purposes.

The direct observations came from field notes that were taken during the research process and from the author's own experience, since he has also served as a special operations operator in Afghanistan. Furthermore, we have also collected data from the frequent discussion with NATO servicemen about their judgement regarding the Portuguese special operations forces contribution to NATO and, consequently, to Afghanistan. The informal discussions were registered and once they provided a better understanding of the phenomenon, they were taken into account.

We also collected official documents from NATO website that were relevant to provide the Resolute Support Mission perspective and the commander intention about all NATO countries contribution to the overall mission.

To analyse the collected data, we defined a set of categories and subcategories to search associations between the various sources of data collection. Then we sought to establish relations between the various categories in order to draw conclusions. The NVIVO10 was used as a qualitative data analysis software to organize, analyse and finds insights into unstructured or qualitative data.

\section{Findings}

This section provides an empirical summary of the data analysis, which includes real-life statements from the respondents.

The most valued aspect attributed by the US special operations forces is regarding the knowledge acquisition by the Portuguese forces. The respondents believed the Portuguese special operations forces are looking forward to acquire new experiences and new competencies through the contact with other international military forces, especially in counterinsurgent environments. This exchange of experiences is allowing the Portuguese servicemen to increase their technical skills, which can be boosted by continued experience sharing with contributing NATO nations. These relationships mainly promote the exchange of relevant information that allows technical innovation with European partner. A US special operations serviceman shares this view:

I believe that Portugal is participating at this NATO mission (Afghanistan) to intensify its relations with the United States and to better know our modi operandi. This aspect is relevant for us because it allows for a better interoperability within NATO, but also because we can work with our allies (special forces operator, 32 years old, US)

The US special operations operators also consider Portugal as a strategic partner relevant to the USA, as it is a country within the European Union that allows strengthening the transatlantic ties, because of its relative proximity to the USA-being the most western country in Europe. They believe it is increasingly relevant to have a 
close cooperation with the Portuguese special operations forces, as well as with all the European countries, as they take into account the European contribution to the international security-cooperative security. The arguments are well evidenced in by a US special forces team leader:

Portugal has a very close relationship with the US. To my best knowledge, we have a US base in a Portuguese Island (Azores) that works as a strategic platform to Europe. The relationship we have with Portugal is not only due to its geographical position, since we also have had several special operations exercises, namely cross training in infiltration techniques (special forces team leader, 42 years old, US)

From the second group of respondents, it was possible to ascertain that the most valued aspects were the participation in missions that have contributed to peace and international security, especially the ones that have strengthening the presence of the Portuguese in international organizations. They believe that Portugal has a stable international status as a western democracy, a full member of the EU and NATO, which gives the country the possibility to actively participate in the international panorama. The participation in international missions, namely through elite forces, creates bonds between Portugal and the countries of the alliance and contributes to improve the country's visibility and credibility. These arguments are well evidenced by the statement of a Portuguese special operations operator:

The Portuguese special operations forces were created as a counter-insurgency unity for the Portuguese operations in Africa, during the colonial war period (1961-74). After the revolution of April 25th, 1974, the Portuguese special operations had to change their way of employment. The special operations are now used as an icon of national sovereignty, which acts in the international context as a co-producer of security while working with their international partners (special forces operator, 32 years old, Portugal)

These respondents also believe the use of the Portuguese special forces intensifies the relations and defence cooperation with the US military. A good example they provided is the participation of the Portuguese Commandos in Kabul Capital Division, at the time under the mandate of the International Security Assistance Force (ISAF) and, very recently, with the deployment of special operations forces to which were assigned several roles, e.g. intelligence, ministerial engagement, etc., under the mandate of the Resolute Support Mission (RSM).

The Portuguese special forces have long contributed to the develop of the Afghan National Defence and Security Forces capabilities. I personally work with the General Command of Special Police Unit (GCPSU), which is an Afghan police unit responsible for responding to high-profile attacks and to conduct high-risk arrests. The most important for us is to participate in the peacekeeping operations and to strengthen the Portuguese presence within the international institutions i.e. NATO. Yes, the Portuguese special forces are operating in Afghanistan almost since the beginning of the conflict, I am just a small piece this wellorganized and very professional institution (special forces operator and ministerial advisor, 34 years old, Portugal)

During the discussions, we also noticed that Portugal is seeking new dynamics, based on the democratic values, the rule of law and the human rights, and thereby find new avenues of influence. We observed that the Portuguese special operations are 
also trying to get more influence within the Afghan Ministry of Interior (rule of law), but also investing on issues such as the gender integration in the Afghan defence and security forces (human rights). Therefore, further research should investigate these topics, i.e. new strategic priorities for GIRoA and the NATO. For instance, it would be interesting to investigate how the Portuguese special operations forces can improve the integration of Afghan women into their special operations force units.

The data analysis also demonstrated the Portuguese special operations missions-military assistance, falls under the overall mission of the NATO special operations component command. Regarding the political foreign objectives, the Portuguese special operations forces capacities and the missions performed by the NATO special operations forces are perfectly aligned and have two main goals:

(1) influence the long-term strategy and sustainability of the Afghan defence and security forces.

I feel that we have an effective influence on the defence and security policy. Our Afghan counterparts are generals and politicians form the Afghan Ministry of Interior. At the same time that we have received the milestones from NATO and Portugal, we can decisively influence the long-term sustainability of the Afghan special forces (informal discussion) and, to develop activities (2) which can strengthen its international present and to stimulate cooperative security relations with their international partners.

In recent years there has been an increase of special operations servicemen to be deployed to Afghanistan, which may be a reflection of this policy (field notes)

By using its elite forces in Afghanistan as instrument of foreign policy, Portugal reaches: 1 national vector, 4 strategies and 4 lines of action, from the PNDS. Table 1 summarizes the selected vectors, strategies and actions by the respondents.

In light with the above, we view the Portuguese strategy in Afghanistan from two different perspectives. At first, it was interesting to observe that questions related to the scope of the Portuguese mission in Afghanistan, i.e. military assistance, the military discourse was focused on strengthening the Portuguese presence within the international institutions and the military participation in peacekeeping operations, in particular contexts such as the UN, NATO and EU (Table 1-light grey). However, when we evaluated the Portuguese foreign policy, we cross-checked the interviews from both groups of respondents and we verified the existence of a strong relation between the USA and Portugal, with the intention to keep strengthening the transatlantic bonds (Table 1 - dark grey).

The Portuguese strategies and line of action are consistent within the PNDS, i.e. all the strategies and lines of action falls under the same national vector: to exercise sovereignty, neutralize threats and risks to national security (vide Table 1). The purpose of this vector is to defend national interests and guarantee the security and defence of Portugal, reduce vulnerabilities and execute the international responsibilities of the state and contribute to the realization of the Portuguese vision of the constructive values of the international order [27]. 


\section{Concluding Remarks}

We have concluded that Portugal is trying to intensify its international relations within the EU, UN and NATO. To this end, the Portuguese armed forces have been playing an important role to strengthen its presence within the international institutions. We have verified that the Portuguese special operations operators are trained well enough to operate in complex environments, as the Afghan mission falls under one of the main special operations missions - the military assistance. In other words, the mission that brings the Afghan Ministerial capabilities to been raised is suitable for the Portuguese special forces.

Portugal, as a small European state, has also tried to contribute along with the USA to spread the rule of law. In Afghanistan, once NATO moved from a combat role to a TAA mission, the Portuguese special operations forces have been developing a strategy to build the Afghan Government, as well as the Afghan National Defence and Security Forces. Thus, under the NATO special operations component command, the Portuguese special operations operators have played one of the most demanding missions in the contemporary Portuguese military history. We therefore closely observed some Portuguese servicemen that helped decisively to develop the capabilities of the Ministry of Interior, in order to operate the Afghan police forces and its special units, e.g. GCPSU.

What is new is that Portugal is seeking new dynamics-based on the democratic values, the rule of law and the human rights - to dissociate itself from the colonial legacy. Portugal is therefore, trying to get more influence, by using its armed forces, to rebuild fragile states in remote geographical areas, along with their international partners.

This paper also presents some limitations, as the identity of the respondents may not be revealed, thus to clarify any questions to address this subject the first author should be contacted. The number of interviews was also limited, once it was restricted to the number of respondents available in a specific period of time. The study is also exploratory in nature and it lacks generalization. The lack of generalization is due to different political goals and different existing types of special forces; thus, the results may differ across NATO countries. Nevertheless, we do believe this study may be useful to other researchers, in the extent that are no similar studies so far; to practitioners, this paper may be relevant too, as it can provide new and fruitful insights into the strategic engagement of special operations forces in fragile states.

\section{References}

1. Seddon, D.: Imperial designs. Crit. Asian Stud. 35(2), 175-194 (2003)

2. Jones, S.: In the graveyard of empires: America's war in Afghanistan. WW Norton \& Company, New York (2010)

3. Miller, P.: Graveyard of analogies: the use and abuse of history for the war in Afghanistan. J. Strateg. Stud. 39(3), 446-476 (2016) 
4. Nojumi, N.: American State-Building in Afghanistan and its Regional Consequences: Achieving Democratic Stability and Balancing China's Influence. Rowman \& Littlefield (2016)

5. NATO.: NATO and Afghanistan. North Atlantic Treaty Organization (2016). http://www.nato. int. Accessed 1 Dec 2018

6. AJP 3.5.: Allied joint doctrine for special operations. North Atlantic Treaty Organization (2013)

7. NATO SOF.: NATO special operations headquarters: Special operations forces. Military Assistance Handbook. 1st study draft, North Atlantic Treaty Organization (2014)

8. AAP-06.: NATO glossary of terms and definitions. North Atlantic Treaty Organizations. 2-D-7 and 2-S-9 (2013)

9. Long, A.: NATO special operations: promise and problem. Obris 58(4), 540-551 (2014)

10. Dellinger, B.: Special operations command Europe: strengthening partnership for global security. Spec. Warf. (2012)

11. Chefe de Estado-Maior do Exército.: Âmbito de atuação, missões e tarefas das unidades de tropas especiais. Divisão de Planeamento de Forças, diretiva ${ }^{\circ} 9$ do Chefe de Estado-Maior do Exército (2007)

12. Livingston, T.: Building the capacity of partner states through security force assistance. Security Force Assistance in the Development of Foreign Forces. Nova Science Publishers (2011)

13. Strandquist, J.: Local defence forces and counterinsurgency in Afghanistan: learning from the CIA's village defense program in South Vietnam. Small Wars Insur. 26(1), 90-113 (2015)

14. Anderson, D., Ernst, J.: The war that never ends: new perspectives on the Vietnam War. University Press of Kentucky (2014)

15. Tucker, S., Roberts, P.: The encyclopedia of World War II: A political, social, and military history. ABC-clio (2004)

16. Grochowski, G.: Planning for the next Takur Ghar. Def. Secur. Anal. 31(2), 152-158 (2015)

17. Teixeira, N.: Breve ensaio sobre a política externa portuguesa. Relações internacionais, R:I(28), 51-60 (2010)

18. Ruivo, L.: Conceito estratégico de defesa nacional contributos para uma revisão. Boletim Ensino, Instituto de Estudos Superiores Militares (2011)

19. Silva, J.: As forças armadas como instrumento de política externa portuguesa no actual contexto internacional. Trabalho Individual de Longa Duração do Curso de Promoção a Oficial General, Instituto de Estudos Superiores Militares (2006)

20. Azambuja, M.: As Nações Unidas e o conceito de segurança coletiva. Estudos Avançados 9(25), 139-147 (1995)

21. Serronha, M.: A cimeira de Lisboa: Uma NATO para o século XXI. Instituto de Defesa Nacional $126-5^{\mathrm{a}}$ série, $37-46$ (2010)

22. Santos, J.: O conceito estratégico da NATO: Superar contradições, manter a coesão. Nação e Defesa, 37-46 (2010)

23. Barratt, M., Choi, T., Li, M.: Qualitative case studies in operations management: Trends, research outcomes, and future research implications. J. Oper. Manag. 29(4), 329-342 (2011)

24. Yin, R.: Case study research design and methods. Appl. Soc. Res. Methods Ser. 5 (2003)

25. Benbasat, I., Goldstein, D., Mead, M.: The case research strategy in studies of information systems. MIS Q. 369-386 (1987)

26. Quivy, R., Campenhoudt, L.: Manual de investigação em ciências sociais (1998)

27. Governo de Portugal.: Grandes opções do conceito estratégico de defesa nacional (2013). https://www.parlamento.pt/sites/COM/Paginas/DetalheNoticia.aspx?BID=5034. Accessed 1 Dec 2018 